\title{
ARTIGOS
}

\section{RATE OF REVERSION OF HEPATOSPLENIC SCHISTOSOMIASIS AFTER SPECIFIC THERAPY}

\section{Reynaldo Dietze and Aluizio Prata}

Seventy patients with hepatosplenic schistosomiasis were treated with oxamniquine. The patients lived in an endemic area and were evaluated 6,18 and 24 months after treatment, during which time transmission in the area was interrupted. After treatment, clinical improvement occurred in $49(70 \%)$ of the patients, as seen by reduction in visceromegaly and reversion of liver nodules. Reversion of hepatosplenic disease occurred in $28(40 \%)$ patients and in liver nodularity in $26(47.3 \%)$ patients after 24 months. Reversion of hepatosplenic disease was seen in $12(21 \%)$ patients and liver nodules disappeared in $4(8.5 \%)$ as early as 6 months after treatment. In general, hepatosplenomegaly reverses earlier than liver nodularity. It is notable that reversion of hepatosplenic disease occurred in many individuals with a history of previous treatment and also in some with advanced age. In four cases this clinical form of the disease had existed for 20 years.

Therefore, there must exist factors other than age and duration of the condition which determine the reversibility of this clinical form. Our results reinforce the concept that, in patients with hepatosplenic disease without esophageal hemorrhages, specific treatment should preceed surgical intervention even in those with a history of previous treatment. At least 18 months should be allowed for the effects of treatment to be manifest. disease.

Key words: Schistosomiasis. Treatment. Oxamniquine. Reversion of hepatosplenic

After 1922 mass treatment of schistosomiasis in Egypt gave the first indications that the prevalence of serious forms of the disease could be reduced as a consequence of specific therapy ${ }^{19}$. The same observation was made by Sette ${ }^{10}$, after treating patients in Catende, Pernambuco (Brazil). Caio Benjamin Dias ${ }^{4}$, in addition to mentioning the benefits of treatment in the prevention of hepatosplenic forms of the disease, suggested the possibility of reversion of these forms "when not yet formed of irreversible lesions." Rodrigues da Silva " emphasized the benefits that could result from treatment in the prevention of severe forms of schistosomiasis. Kloetzel ${ }^{7}$ demonstrated that the

This research was supported in part by Grant DAMD1784-G-4004 from the US Army Medical Research and Development Command, administered at the University of Brasilia under Cooperative Project Registry No. 08280132. The views of the authors do not purport to reflect the positions of the cooperating agencies nor does the use of trade names or commercial sources imply endorsement.

Address reprint request to: Núcleo de Medicina Tropical e Nutrição, Universidade de Brasilia. Cx. Postal 15-3121, 70919 Brasilia, DF, Brasil.

Recebido para publicação em 25/11/1985 number of eggs in feces diminished after treatment, in spite of reinfections and that treatment would prevent the occurrence of clinically severe forms. Bina 2 confirmed that treatment could prevent hepatosplenic disease. Bina and Prata ${ }^{3}$ demonstrated the disappearance of hepatosplenic disease in some patients when this had lasted for less than six years.

The object of this study was to ascertain the effect of specific therapy on the reversion of hepatosplenic schistosomiasis and to determine the rate at which reversion proceeds.

\section{MATERIALS AND METHODS}

This study was conducted in Caatinga do Moura, Bahia, Brazil, an area hyperendemic for schistosomiasis, where a project for control of the disease was initiated in 1982 . Seventy patients were classified as having hepatosplenic schistosomiasis according to the criteria of having the left lobe of the liver enlarged, usually prominent, hardened and/or nodular, and a spleen palpable in the absence of inspiration ${ }^{13}$. Those patients which, after treatment, did not meet at least one of these criteria were considered to have had a reversal of 
Dietze R, Prata A. Rate of reversion of hepatosplenic schistosomiasis after specific therapy. Revista da Sociedade Brasileira de Medicina Tropical 19: 69-73, Abr-Jun, 1986

Table 1 -Rate of reversion of nodules of the liver and the hepatosplenic form of schistosomiasis mansoni after treatment in patients on whom all the clinical examinations were performed.

\begin{tabular}{ccc}
\hline $\begin{array}{c}\text { After Treatment } \\
\text { Months }\end{array}$ & \multicolumn{2}{c}{ Clinical Examination Reversion } \\
\cline { 2 - 3 } & Nodular liver & Hepatosplenic Disease \\
\hline 6 & $2(5 \%)$ & $10(22.2 \%)$ \\
18 & $6(15 \%)$ & $6(13.3 \%)$ \\
24 & $15(37.5 \%)$ & $1(4.2 \%)$ \\
Total of Patients & 40 & 45 \\
\hline
\end{tabular}

Figure 1-Rate of reversion of hepatosplenic disease after treatment in seventeen patients on whom were performed all clinical examination.

Clinical Examination


the hepatosplenic disease. Nodular liver was present in $55(78,6 \%)$ patients. Only one patient admitted to having had hematemesis.

Ages varied from 9 to 74 years, with a mean of 36.6 and a median of 37 years. Fifty $(71.4 \%)$ were females and $20(28.6 \%)$ were males. Forty $(57.1 \%)$ had never had specific treatment for schistosomiasis and $30(42.9 \%)$ admitted to at least one previous treatment. All were passing eggs of Schistosoma mansoni as detected by the Kato-Katz method 6 .

Patients were given a single oral dose of oxamniquine in capsule form using $15 \mathrm{mg} / \mathrm{kg}$ for adults and $20 \mathrm{mg} / \mathrm{kg}$ for children of up to $30 \mathrm{kilograms}$ body weight. The medicine was taken in our presence.

The patients were treated in January, 1983, and evaluated clinically, always by the same observer, before and 6,18 and 24 months after treatment. Because they could not be found at the time of followup, 13 of the patients did not receive the second examination, 11 the third and 11 the fourth. All, however, received at least one clinical examination after treatment. Our index of clinical improvement relative to condition at initial examination was a reduction greater than $2 \mathrm{~cm}$ of splenomegaly or of the left hepatic lobe and a reversion of the nodular liver. Progression in the opposite sense was considered as worsening of the condition.

After treatment two fecal examinations were made, at 6 and 18 months, to determine cure. The patients remained in the endemic area.

\section{RESULTS}

After treatment with oxamniquine, negative stool examinations were encountered at six months and at 18 months in 61 patients $(87.2 \%)$.

The possibility of reinfection was small as a result of the use of molluscicide in the area (Bayluscide). This measure, in addition to drastically reducing the snail population, also reduced to zero the presence of infections in snails and in sentinel mice used to evaluate disease transmission during the time of the study ${ }^{5}$.

Six months after treatment, clinical examination of 57 patients revealed that the size of the left lobe of the liver had diminished in $24(42.1 \%)$ patients, remained unchanged in $28(49.1 \%)$ and increased in $5(8.8 \%)$. The mean reduction in liver size was $3.0 \mathrm{~cm}$. Of the patients evaluated at that time, $47(82.5 \%)$ had nodular livers before treatment. Of these, $4(8.5 \%)$ became smooth after six months. The size of the spleen remained unchanged in $24(42.1 \%)$ patients, increased in $5(8.8 \%)$ and reduced in $28(49.1 \%)$, with a mean reduction of $4.0 \mathrm{~cm}$. Reversion of hepatosplenic schistosomiasis occurred in $12(21 \%)$ patients during this period.
In the clinical evaluation of 59 patients 18 months after treatment, the left hepatic lobe was reduced in $32(54.2 \%)$ patients, remained unchanged in $20(34 \%)$ and grew in $7(11.8 \%)$. The mean reduction was $4.3 \mathrm{~cm}$. Of the patients examined at this time, $48(81.4 \%)$ had nodular livers before treatment. Of these, $11(22.9 \%)$ became smooth to palpation. The size of the spleen remained unchanged in $18(30.5 \%)$ of the patients, increased in $3(5 \%)$ and was reduced in $38(64.4 \%)$, with a mean reduction of $4.4 \mathrm{~cm}$. Reversion of hepatosplenic disease occurred in $23(39 \%)$ patients.

The final clinical examination of 59 patients 24 months after treatment demonstrated that the left hepatic lobe diminished in $28(47.5 \%$ ) of patients, remained unchanged in $25(42.4 \%$ ) and increased in size in $6(10.2 \%)$ patients. The mean reduction in size was $5.7 \mathrm{~cm}$. Of the 59 patients examined, $48(81.3 \%$ ) had nodular livers at initial palpation. Of these, $25(52.1 \%)$ became smooth. The size of the spleen remained unchanged in $25(42.4 \%)$ of patients increased in $4(6.8 \%)$ and was reduced in size in $30(50.8 \%)$, with a mean reduction of $4.9 \mathrm{~cm}$. Reversion of hepatosplenic disease occurred in $22(37.3 \%)$ patients.

Cumulatively, we had reversion of hepatosplenic disease in $28(40 \%)$ patients and of nodular livers in $26(47.3 \%)$. Two patients were sent to government hospitals for splenectomy after examination at 18 months. One of these, (aged 61 years) was done because of hematemesis and the other, (15 years of age) because of anemia related to hypersplenism. Considering both hepatosplenomegaly and the liver surface in the 70 patients, it can be concluded that specific treatment of schistosomiasis improved the condition of $49(70 \%)$ patients. The condition of $6(8.6 \%)$ patients worsened, and the condition of $15(21.4 \%)$ was not changed.

In 45 patients that completed all of the examinations, it was possible to study the rate of reversion. Reversion of hepatosplenic disease was found in $10(22.2 \%)$ patients after 6 months, in 6 (13.3\%) after 18 months and in $1(4.2 \%)$ after 24 months (Table 1). In the same periods, reversion of nodular liver occurred respectively in $2(5 \%), 6(15 \%)$ and $15(37.5 \%)$ patients (Table 1$)$. The regression of spleen occurs earlier than that of the liver nodules (Fig. 1).

Of the 28 patients with reversion of hepatosplenic disease 13 were over 30 years old (Table 2). Their ages varied from 9 to 74 years with a mean of 32.5. Among them were $8(28.6 \%)$ who gave a history of previous treatment $19(67.8 \%)$ who had never been treated and $1(3.6 \%)$ who could not remember. Of the 26 patients with a liver which was no longer nodular, 12(46.2\%) 
gave a history of specific treatment and $14(53.8 \%)$ had no such history.

\section{DISCUSSION}

The reversion of the hepatosplenic form of schistosomiasis can occur soon after specific treatment. In the present study we found that this had occurred in $21 \%$ of those treated within six months. Favourable results can occur later as indicated by our examinations after 18 and 24 months. The percentage of improved patients and of reversion in hepatosplenic disease after specific treatment is similar to that observed by Bina and Prata. ${ }^{3}$ The same occurred in relation to nodular livers. The nodules tended to disappear later than splenomegaly. We believe that the interruption of transmission by snail control did not influence our results since Bina and Prata $^{3}$ obtained a similar percent of reversion of hepatosplenic disease than we did in a study in which transmission was not interrupted.

It is interesting to note that reversion of hepatosplenic disease also occurred in older individuals. In endemic areas the infection is initiated early in life, and hepatosplenic disease is often established before the age of 20.12 Four of our patients already had hepatosplenic disease in 1964.

Table 2 - Data on 28 patients with oxamniquine induced reversion of hepatosplenic disease due to schistosomiasis mansoni

\begin{tabular}{|c|c|c|c|c|c|c|c|c|c|}
\hline \multirow{3}{*}{ Patient $N o$} & \multirow{3}{*}{$\begin{array}{l}\text { Age } \\
\text { (Yrs.) }\end{array}$} & \multirow{3}{*}{ Before } & \multicolumn{4}{|c|}{$\begin{array}{c}\text { Extension of Left Hepatic } \\
\text { Lobe }(A C M)\end{array}$} & \multicolumn{3}{|c|}{$\begin{array}{l}\text { Extension of } \\
\text { Spleen }(A C M)\end{array}$} \\
\hline & & & \multicolumn{3}{|c|}{ After } & \multirow[t]{2}{*}{ Before } & \multicolumn{3}{|c|}{ After } \\
\hline & & & $6 \mathrm{mo}$ & $18 \mathrm{mo}$ & $24 \mathrm{mo}$ & & $6 \mathrm{mo}$ & $18 \mathrm{mo}$ & $24 \mathrm{mo}$ \\
\hline 01 & 09 & 7 & 5 & EDB & $\mathrm{ACM}$ & ACM & IMP & IMP & DDB \\
\hline 02 & 10 & 9 & & 4 & & 2 & & IMP & \\
\hline 03 & 11 & 8 & 8 & 8 & 7 & 4 & EDB & EDB & EDB \\
\hline 04 & 12 & 6 & 6 & EDB & 5 & 4 & 3 & EDB & EDB \\
\hline 05 & 12 & 8 & 7 & 4 & & 6 & 6 & $\mathrm{EDB}_{\mathrm{A}}$ & EDB \\
\hline 06 & 12 & 7 & 8 & 6 & 6 & $\mathrm{ACM}$ & EDB & EDB & EDB \\
\hline 07 & 13 & 9 & & 6 & IMP & 5 & & DDB & IMP \\
\hline 08 & 13 & 8 & 8 & 7 & $\mathrm{ACM}$ & $\mathrm{ACM}$ & DDB & IMP & IMP \\
\hline 09 & 14 & 9 & 8 & 6 & 6 & $\mathrm{ACM}$ & $\mathrm{ACM}$ & EDB & EDB \\
\hline 10 & 19 & 11 & 8 & IMP & EDB & 6 & DDB & IMP & DDB \\
\hline 11 & 22 & 9 & 7 & & & $\mathrm{ACM}$ & EDB & & \\
\hline 12 & 24 & 10 & 9 & & 8 & 5 & EDB & & EDB \\
\hline 13 & 29 & 11 & 7 & 8 & 11 & $\mathrm{ACM}$ & DDB & IMP & EDB \\
\hline 14 & 29 & 6 & 7 & 8 & 9 & 6 & 5 & EDB & DDB \\
\hline 15 & 36 & 6 & 3 & EDB & $\mathrm{ACM}$ & 3 & IMP & EDB & EDB \\
\hline 16 & 37 & 10 & 12 & 11 & 11 & $\mathrm{ACM}$ & EDB & EDB & EDB \\
\hline 17 & 42 & 4 & 10 & 8 & 6 & 4 & REB & $\mathrm{ACM}$ & IMP \\
\hline 18 & 42 & $\mathrm{ACM}$ & & EDB & & 9 & & EDB & \\
\hline 19 & 43 & 9 & 8 & 6 & 6 & $\mathrm{ACM}$ & ACM & DDB & EDB \\
\hline 20 & 45 & 11 & 8 & & $\mathrm{ACM}$ & $\mathrm{ACM}$ & DDB & & IMP \\
\hline 21 & 46 & 6 & DDB & DDB & EDB & 5 & DDB & DDB & EDB \\
\hline 22 & 53 & 9 & 8 & & & 4 & EDB & & \\
\hline 23 & 54 & 17 & 10 & IMP & IMP & 6 & 5 & IMP & IMP \\
\hline 24 & 54 & 6 & 9 & 6 & IMP & 10 & DDB & DDB & DDB \\
\hline 25 & 60 & 11 & & 6 & & $\mathrm{ACM}$ & & DDB & \\
\hline 26 & 62 & 1.3 & & 8 & 7 & $\mathrm{ACM}$ & & EDB & EDB \\
\hline 27 & 64 & 9 & & 6 & 8 & 6 & & EDB & EDB \\
\hline 28 & 74 & 12 & 9 & IMP & IMP & 9 & 4 & EDB & IMP \\
\hline
\end{tabular}

ACM $=$ At costal margin

IMP = Impalpable

$\mathrm{EDB}=$ Easily palpable on deep breathing

$\mathrm{DDB}=$ Palpation difficult on deep breathing. 
Thus, treatment is not only beneficial to patients with recently established hepatosplenic disease, as was previously thought. ${ }^{3}$ Therefore, factors independent of the duration of the condition exist which regulate the reversibility of this clinical form of schistosomiasis. It would be important to determine if there exists differences in the type of hepatic fibrosis in those cases which do and do not regress following specific therapy.

The fact that many patients improved, including $8(28.6 \%)$ patients with hepatosplenic disease who had previous treatment, shows that another treatment may be beneficial. We do not know if they had hepatosplenic disease at the time of their previous treatment and if such treatment failed to prevent or cure this clinical form.

These observations indicate that it is inappropriate to attribute only to surgery the improvements seen in hepatosplenic patients presenting without hemorrhages in the digestive system who received both surgical treatment and specific therapy for schistosomiasis. It is evident that, at least among those schistosomiasis patients without a history of bleeding, specific therapy should be prescribed even in those with history of previous treatment. Patients should be followed for at least 18 months before surgical intervention is contemplated.

\section{RESUMO}

Foram tratados com oxamniquine 70 esquistossomóticos, com a forma hepatosplênica. Os pacientes permaneceram na área endêmica e foram avaliados clinicamente antes, 6, 18, e 24 meses após o tratamento. Durante este periodo a transmissão foi interrompida na área. Após o tratamento especifico ocorreu melhora clínica em 49(70\%) pacientes, traduzida por diminuição nas visceromegalias $e$ reversão do figado nodular. Houve reversão da forma hepatosplênica em $28(40 \%)$ e do figado nodular em 26(47.3\%) após 24 meses. A reversão da forma hepatosplênica já havia ocorrido após seis meses em $12(21 \%)$ pacientes e a do figado nodular em $4(8.5 \%)$. Em geral a regressão da hepatosplenomegalia ocorre mais precocemente do que a do figado nodular. Ela foi observada em alguns pacientes com história de tratamento especifico anterior. Interessante assinalar que a reversão da forma hepatosplênica ocorreu também em individuos com idade avançada e que em quatro deles esta forma clínica já estava instalada há pelo menos 20 anos. Portanto devem existir outros fatores regulando a reversibilidade desta forma clínica, independentemente do seu tempo de evolução. Nossos resultados reforçam o conceito de que nos pacientes com hipertensão porta esquistossomótica que não tiveram hemorragias digestivas, o tratamento especifico deve preceder qualquer indicação cirúrgica em pelo menos 18 meses, mesmo em doentes que referem já tê-lo feito antes.

Palavras Chaves: Esquistossomose. Tratamento. Oxamniquine. Reversão da forma hepatosplênica.

\section{REFERENCES}

1. Abdallah A, Saif M, Koura M. The role of chemotherapy in the control of schistosomiasis: experience in Egypt. In: Afro-Brazilian Symposium on Schistosomiasis. Brasilia p. 47-54, 1974.

2. Bina JC. Influência da terapêutica específica na evolução da esquistossomose mansoni. Revista de Patologia Tropical 10:221-267, 1981 .

3. Bina JC, Prata A. Regressão da hepatosplenomegalia pelo tratamento específico da esquistossomose. Revista da Sociedade Brasileira de Medicina Tropical 16: 213$218,1983$.

4. Dias CB. A sindrome hepatosplênica na esquistossomose mansoni. In: Esquistossomose mansoni no Brasil. Debates promovidos pela Sociedade de Gastroenterologia e $\mathrm{Nu}$ triçāo de São Paulo. São Paulo p. 44-52, 1953.

5. Dietze $R$. Controle da esquistossomose através de medidas integradas em uma área hiperendêmica. Tese de Mestrado. Fundação Universidade de Brasilia, Brasilia, DF, 1983.

6. Katz N, Chaves A, Pellegrino J. A simple device for quantitative stool thick-smear technique in schistosomiasis mansoni. Revista do Instituto de Medicina Tropical de São Paulo 14:397-402, 1972.

7. Kloetzel K. Sobre a conveniência da quimioterapia da esquistossomose em população em continuo contato com os focos. Revista do Instituto de Medicina Tropical de São Paulo 5:106-110, 1963

8. Kloetzel K. A suggestion for the prevention of severe clinical forms of schistosomiasis mansoni. Bulletin World Health Organization 37:686, 1967.

9. Martins AV. Plano de tratamento em massa. In: Esquistossomose mansoni no Brasil. Debates promovidos pela Sociedade de Gastroenterologia e Nutrição de São Paulo. São Paulo p. 143-150, 1953.

10. Sette $\mathrm{H}$. O tratamento da esquistossomose mansoni à luz da patologia hepática. Tese para Cátedra da FMUR. Universidade de Recife, Pernambuco. 1953.

11. Silva JR. Valor e importância do tratamento especifico da esquistossomose mansoni no campo da profilaxia. Revista Brasileira de Medicina.14:514, 1957.

12. Prata A, Bina JC. Development of the hepatosplenic form of schistosomiasis. Gazeta Médica da Bahia 68:49. 60,1968 .

13. Prata A. Caracterização da forma hepatosplênica da esquistossomose. In: Prata A e Aboim E. Simposio sobre Esquistossomose. Salvador, Bahia, Ministério da Marinha/Universidade Federal da Bahia,Clínica de Doencas Tropicais e Infectuosas p. 179, 1970. 